\title{
Panel On: Engaging Communities: The Role of ICTs
}

\begin{abstract}
It is estimated that by the end of 2005, over two billion human beings will be connected to each other through networked systems of mobile communications devices. By that time, the amount of communication that takes place between and among machines will exceed the amount of communication that takes place between and among human beings. It is important, therefore, that we focus our efforts on matching communications technology with societal needs. This panel examines the various ways that ICTs can engage, instruct and empower communities in the $21^{\text {st }}$ century. The topics on this panel include: developing more user-friendly access to information on the Internet; teaching democracy to the emerging class of cyber-citizens; promoting accessibility and digital literacy to ICT users with disabilities; and how NGOs can help foster civic engagement in Eastern Europe through ICTs.
\end{abstract}

\section{Proposed Panelists}

\section{Tim Stephen, University at Albany and Communication Institute for Online Scholarship (CIOS)}

\section{Topic: The CIOS and the VCCE: New Concepts in Interface Technology for a Community Based Resource}

\section{stephen@albany.edu}

Summary: As an experiment using electronic computer networks to enhance academic cooperation and resource sharing, 1986 saw the launch of an online information system for the field of human communication studies (human interaction, rhetoric, journalism, speech, mass communication, etc.). Originally known as Comserve, the system has now sustained 17 years of evolution and enjoys financial support from hundreds of universities. Based upon the norms, traditions, and academic practices of an existing community of scholars, the CIOS's discipline-centered model knits together, enhances, and interweaves resources in a manner tailored to the information needs of a discipline while enhancing scholarship and education with new technologies and data systems. This presentation describes the development and deployment of the CIOS's new Visual Communication Concept Explorer, a new interface technology that capitalizes on the discipline-centric model of the CIOS to show interrelationships between scholars and ideas and to facilitate access to textual resources (i.e., article abstracts, web sites, net discussion, etc.) that bear on those relationships.

\section{Scott A. Webber, University of Colorado at Boulder}

Material published as part of these proceedings, either on-line or in print, is copyrighted by Informing Science. Permission to make digital or paper copy of part or all of these works for personal or classroom use is granted without fee provided that the copies are not made or distributed for profit or commercial advantage AND that copies 1) bear this notice in full and 2) give the full citation on the first page. It is permissible to abstract these works so long as credit is given. To copy in all other cases or to republish or to post on a server or to redistribute to lists requires specific permission from the publisher at Publisher@InformingScience.org

\section{webbers@colorado.edu}

\section{Topic: "Teaching Citizenship in the Digital Age: The Role of ICT"}

Summary: Based on ethnographic fieldwork in elementary schools, the author will argue that preteenage students should be envisioned (and then empowered) as future adult citizens in a democ- 
Panel On: Engaging Communities: The Role of ICTs

racy before they are envisioned (and then trained) as future employees. The focus will be on ways that information and communication technologies might function as tools that can enable opportunities for individual growth and knowledge accumulation rather than merely skills for future employment.

\section{Robert Luke, University of Toronto}

\section{robert.luke@utoronto.ca}

\section{Topic: "Accessibility and Digital Literacy for the Network Society"}

Summary: Digital literacy includes skills required to access technology as well as the ability to critically assess, decode and work within networked environments. This includes the concept of accessibility for those with learning and/or physical disabilities. Promoting accessibility is crucial, not just for those with disabilities; at issue is the free and open access to information that constitutes the lived and material relations of this incipient digital era.

\section{Susan B. Kretchmer, The Johns Hopkins University and Rod Carveth, Texas Tech University}

\section{Topic: NGOs as "Portals" for Civic Engagement: The Case of Poland}

Summary: The euphoria brought about in Central Eastern Europe with the fall of Communist regimes in 1989 brought with it a significant rise in citizen activism in those nations, especially activism that called for a more democratic civil society. Part of this upsurge in citizen participation can be observed by growth of the number of non-governmental organizations (NGOs) in the region. For example, during the 1990s, the number of NGOs in Hungary alone increased twenty-five-fold, from 2000 to 50,000. Part of this growth can be explained by the creation of a more favorable legal environment for such organizations in the post-Communist era, as well as the significant amount of funding provided by U.S. and Western European foundations, such as the Soros Foundation.

As the $21^{\text {st }}$ century emerges, the role of NGOs in fostering more civic engagement is being threatened by the pullout of funding from the region. Hope that this diminution of financial resources won't undercut the foundation built by the present NGOs is sparked by the promise of the Internet and the new information and communication technologies (ICTs) in the region. In Poland, three of the most prominent NGOs utilizing the Internet to foster civil society are the Institute for Democracy in Eastern Europe, the Civil Society Development Foundation and the Klon/Jawor Foundation in Poland. This presentation focuses on how these organizations have used their resources to demonstrate the efficacy of ICTs in civic engagement, and what lessons can be learned for other community networking entities. 